\title{
PENGEMBANGAN ALUR PEMBELAJARAN PERBANDINGAN BERBASIS REALISTIC MATHEMATICS EDUCATION UNTUK SISWA KELAS VII SMP
}

\author{
Netti Kariani Mendrofa \\ Program Studi Magister Pendidikan Metematika FMIPA UNP, Padang \\ email: netti.mend14@gmail.com
}

Submitted: 26-05-2017, Reviewed: 03-06-2017, Accepted: 25-08-2017

\begin{abstract}
Teaching methods ratio that focus on formal procedures do not aid students to develop proportional reasoning regarding the comprehension of concepts or their relationship with daily experiences.Therefore, a learning trajectory was designed, using the Realistic Mathematics Education (RME) approach, to enable the study of comparative approaches which is valid, practical, and effective.The selected research design combines the Plomp model and the Gravemeijer \& Cobb model. The stages of design research in this study were preliminary study phase, prototype development phase, preparation for the experiment, the implementation of the experiment, retrospective analysis and assessment phase. The data derives from interviews, observations, questionnaires, and assessed learning outcomes.The data was processed descriptively. This research resulted in a learning trajectory for concept comparison utilising the RME approach. This learning trajectory consists of discovering the concept of ratio, the concept of direct ratio and inverse ratio, the concept of scale, and the concept ofscale models. This learning trajectory measures valid characteristics relating to contents and constructs. Result of learning trajectories meets the practical characteristic practice in terms of implementation, simplicity and time required. Learning trajectory also meets the characteristics of effective impact on mathematical reasoning abilities of learners where the average results of test of mathematical is 75,29\% with good categories. In conclution of this research that learning trajectory of ratio within RME development is valid, practical and effective.
\end{abstract}

Keywords: Ratio, Design Research, Realistic Mathematics Education, Hypothetical Learning Trajectory.

Abstrak-. Pengajaran perbandingan yang terfokus pada prosedur formal, tidak akan mampu mengarahkan siswa mengembangkan kemampuan bernalarnya dalam penemuan konsep itu sendiri dan hubungannya dengan pengalaman sehari-hari. Oleh karena ini, dirancang alur belajar topik perbandingan menggunakan pendekatan Realistic Mathematics Education (RME) yang valid, praktis dan efektif. Penelitian ini adalah design research yang mengkombinasikan model Plomp dengan model Gravemeijer \& Cobb. Tahapan design research dalam penelitian ini yaitu fase penelitian pendahuluan, persiapan eksperimen, fase pengembangan prototipe, pelaksanaan eksperimen, analisis restrosfektif, dan fase penilaian. Pengumpulan data dalam penelitian ini menggunakan wawancara, observasi, angket dan tes hasil belajar. Data yang diperoleh diolah secara deskriptif. Penelitian ini menghasilkan alur pembelajaran untuk topik perbandingan dengan pendekatan RME. Alur belajar yang dirancang terdiri dari menemukan konsep perbandingan, menemukan konsep perbandingan senilai dan perbandingan berbalik nilai, menemukan konsep skala dan menemukan konsep model berskala. Dari penelitian ini telah dihasilkan alur pembelajaran yang memenuhi karakteristik valid dari segi isi maupun dari segi konstruk. Alur belajar yang dihasilkan memenuhi karakteristik praktis dari segi keterlaksanaan, kemudahan dan waktu yang diperlukan. Alur pembelajaran juga telah memenuhi karakteristik efektif dari segi dampaknya pada kemampuan penalaran siswa dimana rata-rata hasil tes kemampuan penalaran matematis siswa adalah 75,29\% dengan kategori baik. Ini berarti, hasil penelitian menunjukkan bahwa alur pembelajaran topik perbandingan berbasis RME yang dikembangkan telah valid, praktis dan efektif.

Kata Kunci: Perbandingan, Design Research, Realistic Mathematics Education, Hypothetical Learning Trajectory. 


\section{PENDAHULUAN}

Perbandingan merupakan dasar dalam mengembangkan pemahaman dan kemampuan siswa pada materi matematika lainnya, misalnya pembahasan geometri, trigonometri, aplikasi persentase, dan sebagainya.Dole, Wright, Clarke, \& Campus (2009) menyatakan perbandingan dalam matematika berhubungan dengan problem solving dan aktivitas menghitung pada domain yang melibatkan pecahan, persen, kecepatan, geometri, trigonometri, aljabar, peluang, statistik dan kesebangunan. Selain itu, perbandingan sering digunakan dan dimanfaatkan dalam dunia nyata dan berbagai situasi dalam kehidupan sehari-hari, misalnya dalam memperbesar dan memperkecil foto, perbandingan harga, grafik dam lainnya. Melihat pentingnya peran perbandingan, seharusnya pengajaran perbandingan hendaknya lebih optimal dipelajari siswa dari tingkat sekolah dasar sampai menengah.

Kenyataan menunjukkan jika siswa kesulitan dalam belajar perbandingan. Penelitian yang dilakukan oleh Lamon (2007) dalam Beswik (2011), Sudarman (2006), Raharjanti (2015)menyatakan bahwa perbandingan merupakan materi yang sulit dipahami termasuk permasalahan yang berkaitan pada perbandingan senilai dan perbandingan berbalik nilai. Situasi ini dapat disebabkan salah satunya karena proses pengajaran masih menggunakan prosedur matematika yang tetap dan algoritma untuk memecahkan masalah yang berkaitan dengan perbandingan. Sumarto (2013) juga menyatakan bahwa ketika siswa diajarkan prosedur formal, mereka tidak akan mampu mengembangkan kemampuan bernalarnya tentang konsep perbandingan (proportional reasoning).

Kondisi tersebut juga ditemukan saat melakukan obsevasi dan wawancara dengan beberapa orang guru di SMP.Pada proses pembelajaran biasanya bahan ajar yang digunakan guru adalah buku teks matematika yang disediakan di sekolah tanpa merancang sendiri bagaimana seharusnya topik perbandingan diajarkan. Guru cenderung menyajikan pelajaran sesuai dengan alur yang diberikan oleh buku. Namun, jika dianalisis alur pembelajaran yang terdapat pada buku tidak sepenuhnya mendukung pengetahuan guru dalam mengajarkan pembelajaran lebih memadai.Materi dalam buku disajikan langsung pada konsep tanpa adanya proses melibatkan siswa dalam penemuan guna membangun konsep terhadap materi yang dipelajari. Adapun contoh dan latihan 
soal yang disajikan hanya bertujuan untuk melatih keterampilan berhitung dan menggunakan rumus. Teknik penyajian seperti ini menyebabkan siswa tidak terbiasa menggunakan keterampilan bernalarnya dalam memecahkan suatu masalah.Hal ini mengakibatkan pembelajaran matematika belum berjalan dengan efektif dan belum tepat sasaran.

Pemahaman siswa pada permasalahan perbandingan berhubungan dengan kemampuan bernalar siswa dalam memahami makna dari suatu permasalahan perbandingan. Tanpa penalaran yang baik dan benar dalam memahami permasalahan, sulit bagi siswa untuk menyusun perencanaan penyelesaian masalah, apalagi harus menyelesaikannya dengan benar. Permasalahan ini juga ditemukan oleh peneliti sebelumnya yang mengidentifikasi bahwa sangat sulit bagi siswa untuk memecahkan masalah perbandingan dan penalaran proporsional (Hiebert dan Behr, 1988; van Dooren et al, 2010; Lo \& Watanabe, 1997; Widjaja et al, 2010; Silvestre \& da Ponte, 2012; Dikutip dari Nasution, 2012).

Dalam pembelajaran siswa seharusnya tidak dianggap sebagai penerima pasif yang hanya menerima konsepperbandingan dengan sekedar menggunakan rumus dan prosedur tertentu untuk menyelesaikan suatu permasalahan, tetapi lebih dari itu peserta diberi kesempatan dan dibimbing mengembangkan kemampuan bernalarnya dalam proses penemuan kembali (reinvent) konsep itu sendiri.Untuk mengkondisikan siswa kedalam situasi tersebut, perlu dirancang alur pembelajaran yang lebih menekankan pada keterhubungan konsep dengan pengalaman sehari-hari melalui berbagai aktivitas. Pembelajaran yang membuat siswa memiliki rasa ingin tahu, berpikir kritis dan kreatif, dapat membangun pengetahuan dengan sendiri dan dapat menyelesaikan masalah dengan proses yang benar tidak hanya orientasi kepada hasil akhir.

Desain pembelajaran berdasarkan alur belajar (learning trajectory) dikenal dengan istilah Hypotetical Learning Trajectory (HLT). HLT merupakan alur belajar yang terdiri dari tujuan pembelajaran, kegiatan belajar, dan hipotesis proses belajar untuk memprediksi bagaimana pikiran dan pemahaman siswa akan berkembang dalam konteks kegiatan belajar (Simon, 1995). Alur belajar memberikan petunjuk bagi guru untuk menentukan dan merumuskan tujuan-tujuan pembelajaran yang akan dicapai. Dalam proses memformulasikan HLT, tujuan belajar (learning goals) dapat diuraikan dalam sub-sub tujuan (subgoals), sedangkan proses belajar disusun berdasarkan data empirik. Jika tujuan belajar (learning goals) dapat dikorelasikan dengan proses belajar 
akan mempermudah seorang guru dalam menyusun kerangka kerja untuk mendesain pembelajaran dan penilaian. Penelitianyang dilakukan Baker (2003) menunjukkan bahwa HLT mampu meningkatkan penalaran siswa. Dalam penelitian yang dilakukan Webb (2011) dan Hadi (2006) menunjukkan bahwa HLTmampu meningkatkan pemahaman siswa.

Mendesain pembelajaran yang berkaitan dengan bagaimana kemampuan berpikir dan pemahaman siswa akan berkembang dalam aktivitas belajar, sangat cocok menggunakan pendekatan Realistic Mathematic Education (RME). RME merupakan suatu pendekatan yang berasal dari Belanda.Teori ini berangkat dari pendapat Freudenthal bahwa matematika merupakan bentuk aktivitas manusia dan harus dikaitkan dengan realitas.Dalam pendekatan RME, aktivitas manusia dan matematika harus dihubungkan secara nyata terhadap konteks kehidupan sehari-hari siswa sebagai suatu sumber pengembangan dan sebagai area aplikasi melalui proses matematisasi baik horizontal maupun vertikal (Zulkardi, 2002).

Gravemeijer (1994) menyataan terdapat tiga prinsip utama RME yaitu: (1)Guided Reinventation and Progessive Mathematizing (Penemuan terbimbing dan matematisasi progresif); (2) Didactical phenomenology (Fenomenologi didaktis); dan (3) Self-developed model (Mengembangkan model sendiri). Ketiga prinsip tersebut dioperasionalkan ke dalam lima karakteristik dasar dari RME (Gravemeijer, 1994), yaitu: (a) Phenomenological exploration or the use of contexts (penggunaan konteks); (b) The use of modelsorbridging by vertical instrumens (penggunaan model); (c) The use of students own productions and constructions or student contribution (kontribusi siswa); (d) The interactive character of the teaching process or interactivity (Proses pembelajaran yang interaktif); dan (e) The intertwining of various learning standards.

Penggunaan konteks sebagai starting point merupakan salah satu karakteristik dalam pembelajaran matematika dengan RME. Ini berarti, matematika tidak disajikan dalam bentuk hasil jadi rumus atau konsep yang berkaitan dengan materi tetapi siswa harus mengembangkan kemampuan bernalar dalam menemukan kembali konsepkonsep matematika tersebut.Berdasarkan latar belakang masalah yang dikemukakan di atas, penelitian ini bertujuanmenghasilkan alur pembelajaran materi perbandingan untuk mendukung kemampuan penalaransiswa SMP yang memenuhi kriteria valid, praktis, dan efektif. 


\section{METODE PENELITIAN}

Jenis penelitian ini adalah penelitian pengembangan dengan mengkombinasikan model Plomp dan model Gravemeijer \& Cobb. Untuk mengembangkan alur pembelajaran digunakan model Gravemeijer and Cobb. Model Gravemeijer and Cobb terdiri atas tiga fase yaitu fase preparing for the experiement, conducting the experiment dan analysis restrospective. Untuk mengembangkan produk dari desain pembelajaran menggunakan model Plomp. Model Plomp, terdiri dari tiga fase yaitu fase investigasi awal (preliminary research), fase pengembangan atau pembuatan prototipe (prototyping stage) dan fase penilaian(assessment stage).Fase investigasi awal (preliminary research) terdiri dari analisis kebutuhan, analisis kurikulum, analisis siswa, analisis konsep dan reviu literatur. Berdasarkan hasil analisis pada fase preliminary research, dirancang alur belajar topik perbandingan berbasis RME, untuk operasionalnya dirancang buku siswa dan buku guru.

Pada fase prototyping stage, prototipe yang telah dibuat ini dilakukan penilaian melalui evaluasi formatif. Desain pembelajaran topik perbandingan berbasis RME yang telah dirancang dievaluasi sendiri (self evaluation) dan divalidasi oleh para ahli (expert review). Validasi perangkat dilakukan oleh tiga orang dosen Matematika, satu orang dosen Teknologi Pendidikan dan satu orang dosen Bahasa Indonesia. Setelah dihasilkan desain pembelajaran topik perbandingan berbasis RME yang valid, dilakukan evaluasi orang per orang (one-to-one), evaluasi kelompok kecil (small group) / siklus 1 conducting the experiment dilanjutkan dengan analysis retrospective danuji coba lapangan (field test) ) / siklus 2 conducting the experimentuntuk melihat kepraktisan. Pada fase penilaian (assessment stage), dilakukan penilaian tes kemampuan penalaran pada siswa kelas VII SMP Swasta Pembda 2 Gunungsitoli untuk melihat efektivitas. Data penelitian dikumpulkan melalui lembar validasi, lembar angket respon guru dan siswa, lembar observasi keterlaksanaan desain pembelajaran, lembar wawancara, dan tes kemampuan penalaran matematis siswa.

\section{HASIL DAN PEMBAHASAN}

Kegiatan dalam penelitian ini telah berhasil mengembangkan alur pembelajaran berbasis RME yang valid, praktis dan efektif. Tahapan dalam penelitian ini dilakukan dalam beberapa langkah pengembangan. 


\section{Hasil Preparing For The Experimen}

Tahap ini merupakan tahap persiapan yang bertujuan untuk merumuskan sebuah dugaan alur belajar yang dapat diperluas/diuraikandan diperbaiki ketika pelaksanaan desain eksperimen (Gravemeijer and Cobb, 2013). Pada tahap ini dilakukan analisis pendahuluan yaitu tahap pertama design research Plomp. Kegiatan yang dilakukan meliputi analisis kurikulum, analisis konsep, analasis karakteristik siswa dan reviu literatur. Berdasarkan analisis kurikulum, analisis siswa, analisis konsep dan reviu literatur, maka dirancanglah alur pembelajaran topik perbandingan berbasis RME untuk kelas VII SMP. Dalam hal ini, kegiatan dilanjutkan pada tahap pengembangan prototipe yang dijabarkan sebagai berikut.

a) Perancangan Hyphotetical Learning Trajectory (HLT)

Pada tahap ini yang dirancang adalah Hypothetical Learning Trajectory (HLT), HLT ini didesain mengadopsi HLT Simon (1995) terdiri dari tiga bagian yaitu tujuan pembelajaran, sekumpulan aktivitas untuk memperoleh tujuan dan hipotesisi tentang bagaimana siswa belajar dan berpikir. Tujuan pembelajaran disini dimaksudkan target atau capaian yang harus dipahami oleh siswasetelah menyelesaikan topik atau konsep matematika.Tujuan pembelajaran ditetapkan di awal kemudian dilanjutkan dengan rangkaian aktivitas dan prediksi jawaban siswadan antisipasi jawaban oleh guru dengan memberikan pertanyaan pancingan untuk mencapai tujuan pembelajaran yang sudah ditetapkan.Pertanyaan pancingan diberikan untuk menstimulir kemampuan berpikir siswa agar tujuan pembelajaran yang ditetapkan dapat tercapai.

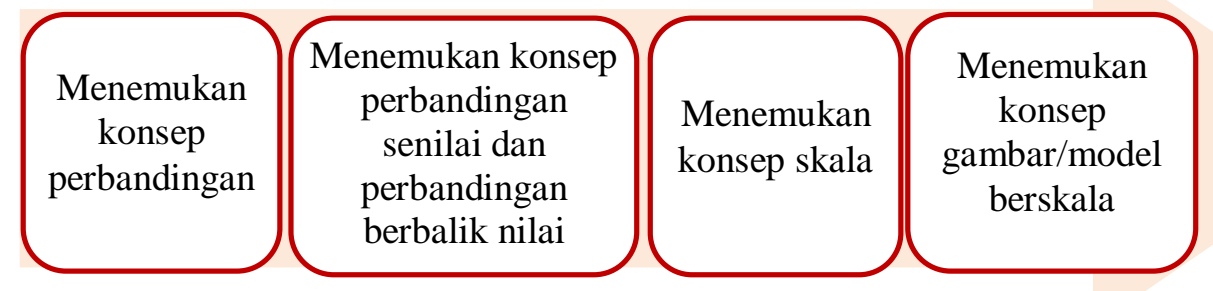

Gambar 1. Rasional HLT

Dalam penelitian topik perbandingan ini dirancang empat HLT, pertama menemukan konsep perbandingan melalui aktivitas pembelian benda-benda yang sering digunakan sehari-hari. Pemilihan aktivitas ini mengarahkan siswa bahwa kegiatan yang dilakukan sebenarnya mengarah pada konsep perbandingan dan memahami apa yang 
sebenarnya dibandingkan dari dua objek/benda yang berbeda dan ketentuan yang perlu diperhatikan dalam membandingkan dua benda.Kedua, Penemuan konsep perbandingan senilai dan perbandingan berbalik nilai melalui aktivitas pembelian pita dan membagi pita. Melalui aktivitas ini mengarahkan siswa pertambahan panjang pita yang dibeli berbanding senilai dengan uang yang harus dibayar, sedangkan saat pita tersebut dibagi maka panjang pita yang diperoleh berbanding terbalik dengan banyak yang menerima. Pada aktivitas berikutnya siswa diminta mendeskripsikan grafik jarak suatu kendaraan dengan kecepatan dan waktu yang diperlukan.

Ketiga, Penemuan konsep skala melalui aktivitas menggambar botol air mineral kemasan dan mengukur jarak dua tempat dalam gambar/denah. Masalah ini dihadirkan dengan tujuan untuk menstimulir siswa menemukan bahwa membandingan ukuran pada peta dengan ukuran sebenar-nya menyatakan konsep skala dari suatu objek. Keempat, penemuan konsep gambar/model berskala melalui aktivitas membandingkan sketsa buku tulis. Aktivitas mengarahkan siswa menemukan bahwa skala dari perbandingan masing-masing sisi antara sketsa buku tulis adalah sama. Selanjutnya, pada aktivitas berikutnya melalui kegiatan meng-gambar lapangan bola voli.

b) Perancangan Buku Guru dan Buku Siswa

Buku guru dan buku siswa yang dirancang dalam pembelajaran RME ini, memiliki beberapa komponen. Komponen bukuguru ini, didesain mengadopsi buku guru Mathematics In context (MIC) pada bab Graping Equation (lihat National Science Fondation, 1998) dan dikombinasikan dengan penulisan buku Diknas. Komponen buku guru yaitu tujuan pembelajaran, alokasi waktu, tentang matematika, ringkasan, rencana penilaian kemampuan siswa, halaman buku siswa dan komentar tentang permasalahan. Sedangkan buku siswa memiliki komponen tujuan pembelajaran, aktivitas siswa, permasalahan kontekstual dan uji pemahaman. Buku Siswa didesain dengan penyajian materi ajar dimulai dari konteks sebagai starting poin pembelajaran sehingga siswa dapat mempelajari topik perbandingan secara bermakna. Masalah kontekstual disajikan dalam setiap aktivitas dan dirancang sedemikian rupa sehingga mengarahkan siswa pada pengkonstruksian berbagai prosedur untuk memecahkan masalah.

3) Validasi Alur Belajar, Buku Guru, dan Buku Siswa

Produk yang telah dirancang dilakukanevaluasi formatifyang dikembangkan Tessmer (2013)untuk menilai kualitas hasil desain produk yang dikembangkan. Pada tahap ini, produk yang dikembangkan terlebih dahulu divalidasi sebelum sampai pada 
tahap pelaksanaan desain eksperimen. Hal ini bertujuan untuk melihat apakah alur pembelajaran yang dikembangkan layak digunakan.

Sebelum mengkonsultasikan dan dinilai oleh pakar, dilakukan evaluasi sendiri, dimana pada tahap ini peneliti dibantu oleh teman sejawat. Pada tahap evaluasi sendiri, ditemukan beberapa kesalahan pengetikan, kalimat yang tidak jelas maknanya dan kesalahan tanda baca. Selain itu, beberapa ketidakkonsistenan penulis dalam menentukan ukuran huruf juga ditemui. Setelah dilakukan evaluasi sendiri, selanjutnya desain pembelajaran divalidasi oleh lima orang validator yaitu tiga orang dosen pakar matematika, satu orang dosen teknologi pendidikan dan satu orang dosen bahasa Indonesia. Pada HLT aspek yang diamati adalah aspek isi dan bahasa.

Tabel 1. Hasil Validasi HLT

\begin{tabular}{|c|l|c|c|}
\hline No. & Aspek yang dinilai & Indeks validasi & Kategori \\
\hline 1. & Isi & 0,729 & Valid \\
\hline 2. & Bahasa & 0,630 & Valid \\
\hline \multicolumn{2}{|c|}{ Nilai validasi } & 0,704 & Valid \\
\hline
\end{tabular}

Selama proses validasi terdapat beberapa revisi yang disarankan oleh pada validator. Nilai validitas HLT secara keseluruhan adalah 0,704 dengan kategori valid. Dengan demikian, dapat disimpulkan bahwa aspek komponen HLT topik perbandingan berbasis RME sudah valid.

Produk implementasi (buku guru dan buku siswa), juga divalidasi. Hasil validasi buku guru dinyatakan dalam tabel berikut:

Tabel 2. Hasil Validasi Buku Guru

\begin{tabular}{|c|l|c|c|}
\hline No. & Aspek yang dinilai & Indeks validasi & Kategori \\
\hline 1. & Isi & 0,727 & Valid \\
\hline 2. & Bahasa & 0,667 & Valid \\
\hline 3. & Penyajian & 0,722 & Valid \\
\hline 4. & Tampilan & 0,667 & Valid \\
\hline \multicolumn{2}{|c|}{ Nilai validasi } & 0,704 & Valid \\
\hline
\end{tabular}

Tabel 3. Hasil Validasi Buku Siswa

\begin{tabular}{|c|l|c|c|}
\hline No. & Aspek yang dinilai & Indeks validasi & Kategori \\
\hline 1. & Isi & 0,711 & Valid \\
\hline 2. & Bahasa & 0,667 & Valid \\
\hline 3. & Penyajian & 0,723 & Valid \\
\hline 4. & Tampilan & 0,667 & Valid \\
\hline \multicolumn{2}{|c|}{ Nilai validasi } & 0,695 & Valid \\
\hline
\end{tabular}


Pada Buku Guru dan Buku Siswa aspek yang diamati adalah aspek dikdatik atau penyajian, aspek materi dan isi, aspek kebahasaan, dan aspek kegrafikan atau tampilan. Selama proses validasi terdapat beberapa revisi yang disarankan oleh para validator. Nilai validitas Buku Guru dan Buku Siswa secara keseluruhan masing-masing adalah 0,704dan 0,695 dengan kategori valid. Dengan demikian dapat disimpulkanBuku Guru dan Buku Siswa berbasis RME yang dirancang sudah valid.

\section{Hasil Conducting The Experiment dan Retrospective Analysis}

Setelah semua produk yang dikembangkan berkategori valid, selanjutnya dilakukan kegiatan mengujicobakan alur pembelajaran yang telah dirumuskan. Kegiatan itu bertujuan menguji dan memperbaiki dugaan alur belajar serta melihat kepraktisan dari alur belajar yang telah dirancang. Kegiatan diawali dengan one-to-one evaluation (evaluasi perorangan)yangdilakukan dengan tiga orang siswa kelas VII SMP Swasta Pembda 2 Gunungsitoli dengan kemampuan rendah, sedang dan tinggi. Evaluasi one-to-one yang dilaksanakan secara umum berfokus pada penyajian masalah yang sulit dipahami, kemudahan dalam penggunaan melalui petunjuk yang diberikan, keterbacaan kalimat yang disajikan serta ketertarikan terhadap buku siswa yang dirancang tersebut.Evaluasi dilakukan dengan memberikan Buku Siswa kepada peserta didik untuk dibaca dan diselesaikan, kemudian dilakukan wawancara secara informal untuk meminta tanggapan mereka terhadap alur belajar yang ada dalam buku tersebut.Berdasarkan hasil wawancara dengan siswa, secara umum siswa berkemampuan tinggi, sedang dan rendah dapat memahami masalah kontekstual yang dihadirkan dalam masalah kontekstual yang dijadikan sebagai starting point dalam menemukan setiap konsep.

Setelah dilakukan revisi hasil evaluasi perorangan, dilakukan evaluasi kelompok kecil,yang merupakan conducting experiment siklus pertama pada pengembangan model Gravemeijer \& Cobb. Evaluasi kelompok kecil ini dilakukan pada enam orang siswa kelas VIISMP Swasta Pembda 2 Gunungsitoli yang berkemampuan tinggi, sedang dan rendah.Secara keseluruhan, desain pembelajaran topik perbandingan berbasis RME pada evaluasi ini sudah dapat digunakan untuk pembelajaran perbandingan. Namun, ada beberapa hal yang perlu direvisi, diantaranya untuk beberapa aktivitas dilakukan penambahan kalimat pernyataan pada kesimpulan. Selain itu, dilakukan penambahan pertanyaan pada beberapa aktivitas yang dianggap memudahkan siswa dalam menemukan konsep yang diharapkan. 
Selanjutnya, dilakukan uji coba kelompok besar (field test) yang disebut juga conducting experiment siklus kedua.Pembelajaran ini dimulai dengan diskusi kelas, siswaduduk dalam kelompok yang terdiri dari 4-5 orang. Diskusi kelas ini selain bertujuan untuk membangun dan mengembangkan interaktivitas siswa sesuai dengan karakteristik ke empat RME, juga sebagai stimulir pengetahuan dasar siswa tentang konsep perbandingan.

Penemuan konsep perbandingan dalam penelitian ini dirancang melalui dua aktivitas yaitu membandingkan harga dua barang berdasarkan kuantitasnya dan membagi biskuit dan permen. Aktivitas diawali dengan meminta siswa memahami perbandingan melalui kegiatan menentukan harga termurah dari kedua kemasan dan juga menentukan banyak sabun mandi dan sikat gigi yang dapat dibeli. Berdasarkan jawaban siswa, terlihat bahwa hasil pengerjaan siswa sudah bersesuaian dengan HLT yang dirancang, dimana siswa memperhatikan masing-masing kuantitas kemasan dalam membandingkan kemasan yang termurah. Siswa menggunakan kemampuan bernalarnya bahwa dalam menentukan harga termurah perlu memperhatikan kuantitasnya.

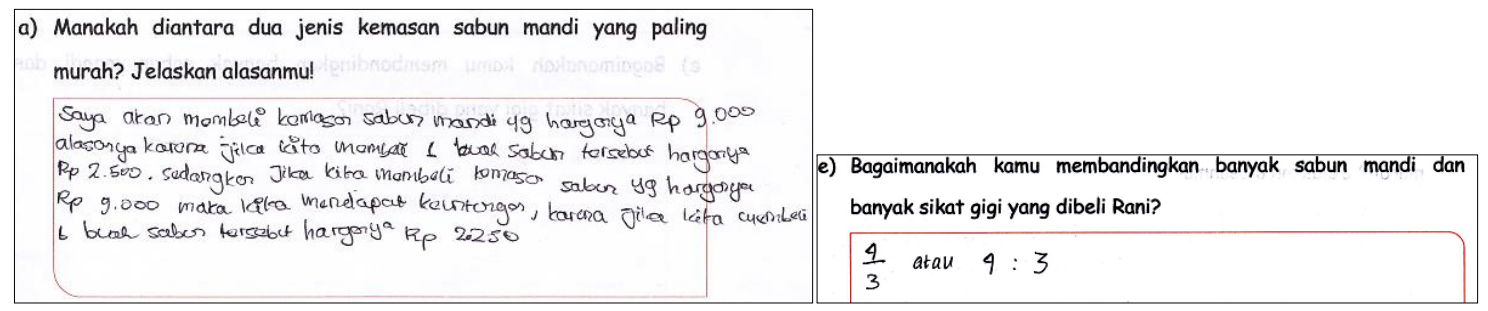

Gambar 2. Strategi siswa dalam aktivitas memahami perbandingan.

Siswa terlihat sudah mampu menyatakan perbandingan berdasarkan permasalahan yang diberikan. Hal ini menunjukkan, bahwa masalah yang diberikan mampu menstimulir siswa memahami konsep perbandingan dan memahami ketentuan dalam menyatakan perbandingan.

Penemuan konsep perbandingan senilai dan perbandingan berbalik nilai dirancang melalui empat aktivitas, yaitu aktivitas menemukan konsep perbandingan senilai dan perbandingan berbalik nilai melalui kegiatan membeli dan membagi pita. Selanjutnya, aktivitas mendeskripsikan grafik perbandingan senilai dan perbandingan berbalik nilai. 


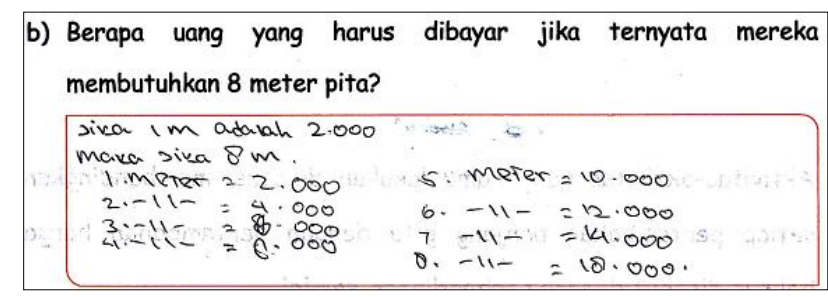

Gambar 3. Strategi siswa dalam menetukan harga pita permeter.

Siswa menyatakan bahwa semakin panjang pita yang dibeli maka harga yang dibayarkan semakin besar. Diperoleh bahwa pertambahan panjang pita berbanding senilai dengan pertambahan harga pita yang dibayar. Selanjutnya, saat pita tersebut dibagi siswa menemukan jika yang terjadi sebaliknya, dimana pertambahan banyak yang menerima berbanding terbalik dengan panjang pita yang dimiliki. Hal ini menunjukkan, bahwa masalah dapat menstimulir siswa menemukan konsep perbandingan senilai dan perbandingan berbalik nilai dan memahami perbedaan permasalahan kedua perbandingan tersebut.
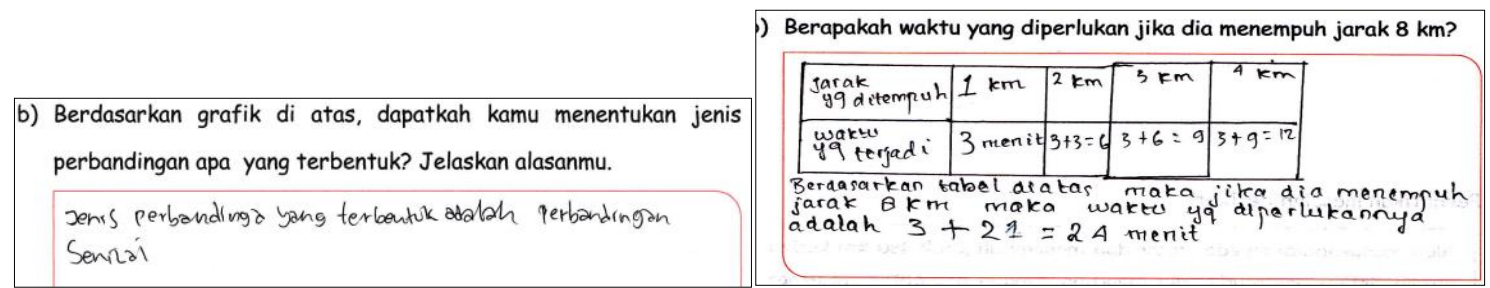

Gambar 4. Strategi siswa mendeskripsikan grafik jarak tempuh berdasarkan waktu.

Telihat siswa mampu mendeskripsikan grafik yang diberikan dan menentukan jenis perbandingan yang terbentuk. Siswa mampu menentukan bahwa jenis perbandingan yang terbentuk dari grafik adalah perbandingan senilai. Aktivitas ini menunjukkan jika masalah yang diberikan mampu mengarahkan siswa menemukan konsep perbandingan senilai melalui grafik dan tabel.

Penemuan konsep skala sebagai suatu perbandingan dirancang melalui dua aktivitas yaitu kegiatan menggambar botol air mineral kemasan serta kegiatan mengukur jarak dua tempat dalam gambar/denah.

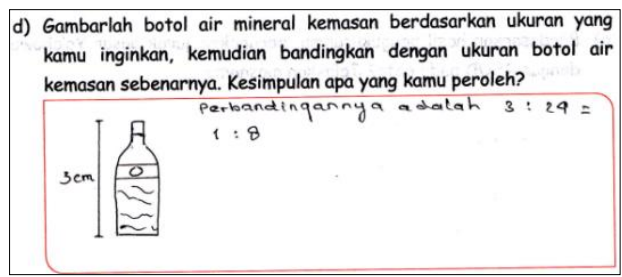

Gambar 5. Strategi siswa dalam menggambar botol air mineral.

Gambaran konsep skala sudah mulai terbentuk dalam pemikiran siswa. Siswa menyadari jika semakin besar sketsa benda yang digambar maka perbandingan ukuran 
gambar dengan ukuran sebenarnya semakin kecil sedangkan sebaliknya jika semakin kecil sketsa benda yang digambar maka perbandingan dengan ukuran sebenarnya semakin besar.

Selanjutnya, pada aktivitas berikutnya menentukan jarak dari dua tempat dari suatu peta, terlihat siswaberusaha mencari dengan melakukan pengukuran dan mencoba membandingan jarak antara dua tempat dalam bentuk sederhana. Siswa juga memahami jika jarak sebenarnya dari lokasi/tempat lain dapat ditentukan dari perbandingan dua tempat telah didapatkan. Proses penyelesaian siswa memperlihatkan bahwa permasalahan yang diberikan sudah mampu menstimulir pemahaman siswa akan konsep skala.

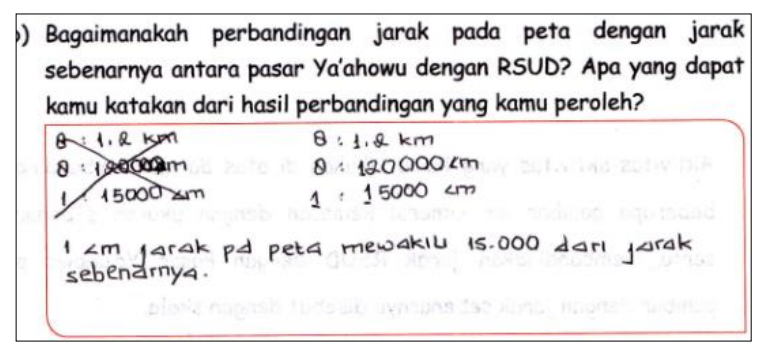

Gambar 6. Strategi siswa dalam menentukan perbandingan jarak dua tempat.

Penemuan konsep model berskala dirancang melalui dua aktivitas yaitu kegiatan yang berkaitan dengan aktivitas membandingkan sketsa buku tulis dengan gambarnya dan menggambar lapangan bola voli. Pada aktivitas pertama, masalah yang diberikan membentuk pemahaman siswa yaitu jika perbandingan masing-masing sisi sketsa dua buku tulis adalah sama, demikian juga dengan perbandingan pada ukuran buku sebenarnya. Siswa menyadari dalam membuat sketsa suatu benda perbandingan sisinya selalu sama. Selanjutnya, berdasarkan aktivitas pertama, menggambar bola voli, siswasemakin memahami bahwa dalam menggambar suatu sketsa maka perbandingan antara masing-masing sisi saling ekuivalen. Proses penyelesaian siswa ini memperlihatkan bahwa permasalahan yang diberikan sudah mampu menstimulir pemahaman siswa akan konsep gambar berskala. 


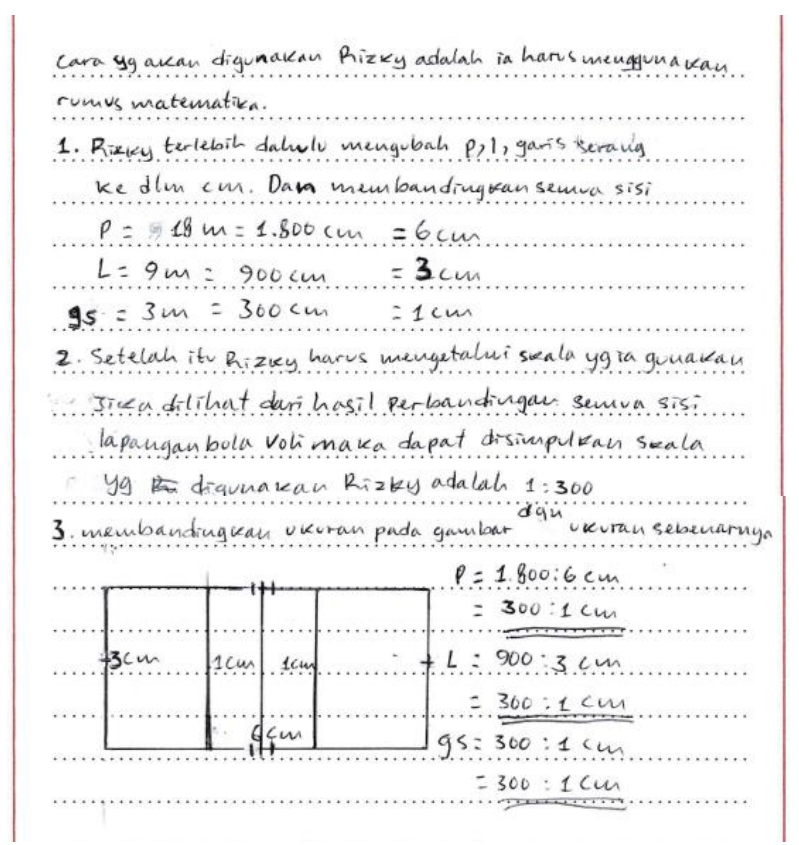

Gambar 7. Strategi siswa dalam menggambar sketsa bola voli.

Melalui proses pembelajaran yang dilakukan, penerapan karakterisktik RME terlihat dari pendesainan pembelajaran ini, dimana menggunakan konteks benda-benda di toko yang sering ditemui siswa. Selain itu, selama pembelajaran adanya keterlibatan siswa dalam berbagai kegiatan seperti berdiskusi, bertanya, menjawab pertanyaan, dan presentasi di depan kelas untuk menjelaskan hasil kerja mereka dan mempertanggungjawabkannya. Selama proses pembelajaran, jelas terlihat bagaimana setiap siswa memiliki strategi/pandangan sendiri yang berbeda dengan pendapat temannya sendiri baik dalam kelompok kecil maupun dalam diskusi kelas.

Setelah proses pembelajaran berakhir, dilakukan retrospective analysis. Tahap retrospective analyses dilakukan secara bergantian dengan conducting experiment. Dalam arti, setelah dilaku-kan kegiatan ujicoba alur pembelajaran untuk setiap tahap, dilakukan analisis restropektif untuk meng-evaluasi setiap kegiatan eksperimen yang telah dilaksanakan. Pada tahap ini, peneliti, guru, dan observer mendiskusikan sejauh mana implementasi dari desain perangkat pembelajaran. Secara keseluruhan Desain pembelajaran topik perbandingan berbasis RME ini sudah dapat digunakan untuk pembelajaran perbandingan. Namun, ada beberapa hal yang perlu diperbaharui, misalnya masalah HLT pada aktivitas 2.1 dan aktivitas 2.2 yaitu konteks harga beli pita dan kegiatan membagi pita, dilakukan perbaikan pertanyaan berkaitan dengan masalah yang diberikan. Perbaikan dalam hal ini, yaitu pertanyaan yang dianggap hampir sama 
dijadikan satu pertanyaan dan selanjutnya ditambah pertanyaan lain yang dianggap lebih mengarahkan siswa dalam menyatakan kesimpulan.

Berdasarkan hasil angket yang diberikan kepada guru dan siswa. Diperoleh hasil berikut:

Tabel 4. Hasil Praktikalitas oleh Guru

\begin{tabular}{|c|c|c|c|c|}
\hline No. & Aspek yang Dinilai & Rata-rata & Persentase & Kategori \\
\hline 1. & Kemudahan Penggunaan & 3 & 75 & Praktis \\
\hline 2. & Efisiensi Waktu & 3,33 & 83,33 & Sangat Praktis \\
\hline 3. & Kemudahan Dipahami & 3,33 & 83,33 & Sangat Praktis \\
\hline 4. & Ekuivalensi Buku Guru & 4 & 100 & Sangat Praktis \\
\hline \multicolumn{2}{|r|}{ Rata-rata Keseluruhan } & 3,25 & 81,25 & Sangat Praktis \\
\hline
\end{tabular}

Nilai kepraktisan desain pembelajaran topik perbandingan yang diperoleh dari angket guru adalah $81,25 \%$ dengan kategori sangat praktis ber-dasarkan kriteriakepraktisan. Dengandemikian dapat disimpulkan bahwa guru menganggap desain pembelajaran topik perbandingan berbasis RME ini praktis digunakan pada kelas VII SMP.

Tabel 5. Hasil Praktikalitas oleh Siswa

\begin{tabular}{|c|l|c|c|c|}
\hline No. & \multicolumn{1}{|c|}{ Aspek yang Dinilai } & Rata-rata & Persentase & Kategori \\
\hline 1. & Petunjuk & 3,43 & 85,78 & Sangat Praktis \\
\hline 2. & Efisiensi Waktu & 3,00 & 75,00 & Praktis \\
\hline 3. & Daya Tarik & 3,44 & 86,03 & Sangat Praktis \\
\hline 4. & Kemudahan untuk Dipahami & 3,64 & 90,88 & Sangat Praktis \\
\hline \multicolumn{2}{|c|}{ Rata-rata Keseluruhan } & 3,38 & 86,63 & Sangat Praktis \\
\hline
\end{tabular}

Nilai kepraktisan desain pembelajaran topik perbandingan yang diperoleh dari angket siswa adalah $86,63 \%$ dengan kategori praktis berdasarkan kriteria kepraktisan. Dari hasil analisis angket yang diisi oleh siswa, desain pembelajaran topik perbandingan mudah digunakan, menarik, dapat dipahami dengan baik, dapat memotivasi siswauntuk belajar matematika dan menemukan konsep dengan baik. Dengan demikian dapat disimpulkan bahwa siswa menganggap desain pembelajaran topik perbandingan berbasis RME ini praktis digunakan pada topik Perbandingan kelas VII SMP.

3. Hasil Fase Penilaian

Untuk melihat keefektifan alur pembelajaran topik perbandingan berbasis RME diperoleh dari hasil tes kemampuan penalaran matematis siswa. Kemampuan Penalaran matematis ini dapat dilihat dari kemampuan siswa memberikan pendapat dengan jawaban atau strategi yang berbeda. Berikut gambaran hasil tes kemampuan penalaran siswa berdasarkan kualifikasi persentase indikator penalaran matematis(Bahri, 2014). 
Tabel 6. Hasil Tes Kemampuan Penalaran

\begin{tabular}{|l|c|c|}
\hline \multicolumn{1}{|c|}{ Indikator Penalaran } & Persentase (\%) & Keterangan \\
\hline $\begin{array}{l}\text { Mengkonstruk atau menilai konjektur/argumen } \\
\text { matematika. }\end{array}$ & 77,94 & Baik \\
\hline Melakukan manipulasi matematika. & 67,65 & Baik \\
\hline $\begin{array}{l}\text { Memberikan penjelasan dengan menggunakan } \\
\text { konsep dan sifat-sifatnya. }\end{array}$ & 76,47 & Baik \\
\hline $\begin{array}{l}\text { Menggambarkan konklusi logis tentang sejumlah ide } \\
\text { dan keterkaitannya }\end{array}$ & 80,88 & Sangat Baik \\
\hline $\begin{array}{l}\text { Menemukan pola atau sifat dari gejala matematis } \\
\text { untuk membuat generalisasi }\end{array}$ & 73,53 & Baik \\
\hline \multicolumn{1}{|c|}{ Rata-Rata Persentase (\%) } & 75,29 & Baik \\
\hline
\end{tabular}

Berdasarkan tabel di atas dapat dilihat nilai rata-rata tes kemampuan penalaran matematis siswa setelah diuji coba adalah 75,29\% dengan kategori baik. Selain itu, melalui soal yang diberikan juga terlihat bahwa rata-rata nilai tes secara keseluruhan yang diperoleh siswa pada materi perbandingan adalah 75,0. Hal ini menunjukkan bahwa soal-soal yang diberikan dapat dipahami oleh siswa dan memberikan gambaran bahwa penerapan alur belajar dengan pendekatan RME dapat menanamkan konsep dasar perbandingan kepada siswa. Sehingga, dapat dikatakan bahwa perangkat pembelajaran yang dikembangkan dapat dikategorikan ke dalam kategori efektif.

\section{KESIMPULAN}

Berdasarkan hasil analisis data yang telah dilakukan dapat disimpulkan bahwa penelitian yang dilakukan menghasilkan alur pembelajaran topik perbandingan dengan karakteristik valid dari segi isi dan konstruk, memenuhi karakteristik praktis dari segi keterlaksanaan dan kemudahan pengunaan, dan memenuhi karakteristik efektif terhadap dampaknya dalammeningkatan kemampuan penalaran matematis siswa kelas VII SMP. Berdasarkan simpulan di atas, maka alur pembelajaran topik perbandingan berbasis RME untuk kelas VII SMP dapat dijadikan sebagai pedoman bagi guru dalam melaksanakan pembelajaran untuk meningkatkan kemampuan penalaran matematis siswa.

\section{DAFTAR PUSTAKA}

Bahri, Syamsul. 2014. Upaya Meningkatkan Penalaran Matematika Siswa Kelas Viii Putra Mts.Al-Muslimun Nw Kebon Kongok Melalui Penerapan Metode Investigasi Kelompok Dalam Pembelajaran Matematika. (Online), Vol. 2. No. 1, hal. 301-309.

Bakker, Artur. 2004. Design research in statistics education on Symbolizyng and Computer Tools. Dissertation Utrecht University - Nederlands. 
Dole, S., Wright, T., Clarke, D., \& Campus, P. (2009). Proportional Reasoning. Making Connection in Science and Mathematics (MC SAM) , 1-18.

Beswick, Kim. 2011. A Realistic Context for Developing Proportional Reasoning with Ratios, (Online). (http://web.a.ebscohost.com/ehost/pdfviewer, diakses pada tanggal 16 Juli 2016).

Gravemeijer, K.P.E. 1994. Developing realistic mathematics education. Utrecht, The Nederlands: Freudenthal Institute.

Gravemeijer, Koeno and Cobb, Paul. 2006. Design research from the Learning Design Perspective. Dalam Jan Ven Den Akker, et. al. Educational Design Research. London: Routledge

Hadi, Sutarto.2000. Teori Matematika Realistik. The Second Tryout of RME-based INSET 2000. University of Twente Enschede, the Netherlands. Tidak diterbitkan.

Langrall, C. W. \& Swafford, J. (2000). Three Balloons for Two Dollars: Developing Proportional Reasoning.Mathematics Teaching in the Middle School, 6(4), pp. 254-261.

Nasution, Andrea Arifsyah. 2014. Supporting Indonesian Fifth-Grade Students to Learn about Proportion. Tesis Online. Surabaya: Pasca Sarjana Universitas Negeri Surabaya

Plomp, T. 2013. Educational Design Research: an Introduction. Dalam Tjeerd Plomp dan Nienke Nieveen (Ed.). An Introduction to Educational Design Research. Enschede: SLO $\cdot$ Netherlands Institute for Curriculum Development

Raharjanti, 2016. Kesalahan Siswa dalam Menyelesaikan Permasalahan Perbandingan Senilai dan Berbalik Nilai. ISSN: 2502-6526. KNPMP I. 312-319.

Silvestre,A.I.,\& da Ponte J.P. (2012). Missing value and comparison problems: What pupils know before the teaching of proportion. PNA, 6 (3), $73-83$.

Simon, Martin A. 1995. Reconstructing Mathematics Pedagogy from a Conswtructive Perspective. Journal of Research in Mathematics Education. Vol. 26. No.2. 135137.

Sudarman, 2006. Meningkatkan Kemampuan Siswa Menyelesaikan Soal Perbandingan dengan Pembelajaran Matematika Realistik Siswa SMPN 4 Palu. Vol. 2. No. 2.

Sumarto, Sylvana Novilia. 2013. Design Research On Mathematics Education: Ratio Table In Developing The Students' Proportional Reasoning. Vol. 7, No. 1. pp 69-80. 
Tessmer, M. (1994). "Formative Evaluation Alternative".Performance Improvement Quarterly, 7 (1), 3-18.

Webb, David C. 2011. Design Research in the Netherlands: Introducing Logarithms Using Realistic Mathematics Education. Journal Spring-Summer 2011, Volume 2. hal.48-52.

Widjaja, W. (2010). The Role of Context and Teacher's Questioning to Enhance Students' Thinking. Journal of Science and Mathematics Education in Southeast Asia, 2(33), pp. 168 - 186.

Zulkardi. (2002). Developing a Learning Environment on Realistic Mathematics Education for Indonesian Student Teacher. The Netherlands: Twente University. 